\title{
False Idles:
}

\section{The Politics of the "Quiet Life" in Greek and Roman Antiquity}

\author{
Eric Brown
}

\section{The Ideology Opposed to Withdrawal}

In Thucydides' History, Pericles gives the funeral oration for the first of the Athenian war-dead, and he calls the living to arms by praising their way of life. In Athens, he says,

In the same men there is concern both for their own affairs and at the same time for those of their fellow-citizens, and those who are busy with their work know enough about public affairs, for we alone think that the man who takes no part in public affairs is not unbusied (apragmōn) but useless (achreios). (Thuc. 2.40.2)

The Athenians, says Pericles, participate in politics, and they scorn the man who avoids the business (ta pragmata) of the polis. Other Greeks might say, interchangeably, that such a man is "unbusied" (apragmōn) or that he "minds his own business" (to ta hautou prattein). But Pericles insists that Athenians do not accept these labels. They rebuke him. ${ }^{1}$

Despite Pericles' rhetoric, this attitude was common throughout the Greek world. (Indeed, the Athenian citizenry, with its democratic freedoms, was among the least rigorously committed to political engagement. That is why Pericles has to try to inspire greater commitment.) Moreover, there was good reason for the widespread hostility to quiet withdrawal from politics. Throughout the Greek world, the security of the polis depended upon its citizens. Anyone who withdrew from politics to live a quiet life was a "free rider," reaping benefits of the city without contributing his fair share of effort (cf. Plut. Adv. Col. 1127a). Worse, his 
inattention made him useless when trouble comes to the polis. During war, especially, the city needed the help of every citizen.

Not that the opposition to the quiet life was limited to wartime. In Plato's Republic, Socrates imagines a "good father who lives in a polis that is not well governed, who avoids honors, political office, lawsuits, and all such 'busybodiness' (philopragmosunēn), and who is willing to be disadvantaged to avoid business (pragmata)" (549c1-5). Socrates also imagines what this man's wife will say about him:

She complains that her husband is not one of the rulers and that this disadvantages her among the other women, and then she sees that he is not very serious about money, that he does not fight or squabble in private courts or public assembly, but that he bears all such things easily, and when she perceives that he is always absorbed in his own thoughts, not much regarding or disregarding her-as a result of all these things, she complains and says that he is unmanly and too easygoing. (549c7-d7) The nagging wife is not alone. The man's son hears similar things from the household slaves (549e2-3), and "when he goes out, he hears and sees other things of this sort: men who mind their own business (tous ta hautōn prattontas) in the city are called fools and of little account, while those who do not are honored and praised" (550a1-5).

Call this the dominant ideology. It attaches honor to the busy, political life and dishonor to the unbusied, quiet life. It contrasts the manly vigor of public action with the feminine weakness of private withdrawal. Politics, on this conception of value, is a necessary outlet for human excellence. ${ }^{2}$

The dominant ideology waxed and waned but persisted throughout antiquity. It is commonly believed that polis-centered life collapsed in the wake of Alexander the Great's 
conquests, but the dominant ideology continued to exert force throughout the Hellenistic period under the successor kingdoms. Nor was it limited to Greece. Rather, it underlay Cicero's appeals for political action in the prologue to On Republic and in the first book of On Duties. And it remained a force at the end: Augustine wrote City of God to defend the Christians from the charge that their withdrawal from public affairs left Rome vulnerable to the barbarians.

But the dominant ideology did not go unopposed. In this chapter, I show how defenders of the quiet life challenged the view that ordinary political engagement should be central to the lives of citizens. To find these challenges, I concentrate chiefly on philosophical writings. ${ }^{3}$ Greek and Roman philosophers engaged in a long-standing dispute about whether it was best to live as an active citizen or as a detached philosopher, and this debate offers a rich source of reasons to resist the dominant ideology. I focus on three distinct challenges, with the aim of taking the measure of their significance for ancient political thought.

\section{Three Defenses of Withdrawal}

Although I will focus on philosophical writing, I begin with Euripides' Antiope because this play raises all three challenges and reminds us of the intellectual connections between authors that modern academe too often keeps apart. Only fragments of Antiope survive, but they record an interesting disagreement between two brothers. Zethus accuses Amphion of betraying his "noble nature (gennaian phusin)" by taking on a "womanish shape" and refusing to "offer vigorous counsel" (fr. $185 T G F)$. He charges,

Any man well-equipped for life who neglects the affairs of his house and runs after the pleasures of music and dance will be useless (argos) to his house and the city and a 
nobody to his friends. One's nature (phusis) is ruined when one gives way to sweet pleasure. (fr. $187 T G F)$

Zethus also singles out for scorn the pleasures of intellectual inquiry, and he beseeches Amphion to reject "these refined subtleties" and "idle babbling" that threaten his house and weaken his city (frr. 188 and $219 T G F$ ).

But Amphion can offer three distinct replies. First, he can defend his quiet pursuit of pleasure. This involves two distinct moves. Amphion first has to defend the pursuit of pleasure in general. He argues that uncertainties governing other pursuits make it a reasonable option (cf. Horace, Odes 1.11):

Such is the life of struggling mortals: not always fortunate or unfortunate; sometimes successful and sometimes not. Since we are faced with uncertain blessedness, why should we not live as pleasantly as we can and avoid pain? (fr. 196 TGF)

Amphion's second move is to insist that the best route to pleasure leads not through politics but through quiet withdrawal. He says, "He who busies himself in many things (prassei polla) that he might avoid is a fool, when he might live pleasantly as an unbusied man (apragmōna)" (fr. $193 T G F)$. The two steps of this argument are related. In a life of public engagement, one struggles against rivals to secure honor, prosperity, and security for oneself and one's friends. But the goals of such competition are subject to fortune. Amphion argues that it is more sensible to pursue a goal that one can achieve reliably and that one can achieve one's goal reliably if one pursues pleasure in a quiet life.

Amphion can also defend the life of quiet withdrawal by defending more particularly the intellectual inquiries that Zethus scorns. Another fragment that might belong to Antiope suggests 
how he could do this. This complicated fragment contrasts the life spent studying nature with sordid business:

Blessed is he who gives his attention to research, desiring neither the misery of his fellow-citizens nor unjust actions, but contemplating the ageless order of immortal nature - how it is constituted, and whence, and why. Concern for shameful deeds never sits near such things. (fr. $910 T G F)^{4}$

Again, Amphion draws attention to the competition that political life involves. Such competition involves wishing ill to one's rivals and temptations to do wrong to promote one's own projects. So even when things work out fortunately, politics is a disagreeable way of procuring what one wants. Quiet study, by contrast, is entirely free of such nastiness. It is not a disagreeable way of procuring what one wants; it is something that one wants. Quiet study simply makes one blessed because it is, if not valuable for its own sake, at least intrinsically pleasant. (If it is intrinsically pleasant, it brings about pleasure all by itself, and pleasure, according to Amphion, is valuable for its own sake.)

Third, and perhaps most surprisingly, Amphion can argue that his detached life makes him a more effective citizen. Again, his argument has more than one part. His general claim is that wise advice takes precedence over manly vigor:

With a man's sound advice a city and a house thrive, and there is, in addition, great strength for war. For one bit of wise counsel conquers many hands, and ignorance is the greatest evil with the mob. (fr. $200 T G F$ )

Then Amphion suggests that he will be a more effective source of wise advice:

I hope I shall have a sense of proportion (aidōs) and say something wise, and so make no disturbance which harms the city. (fr. $202 T G F$ ) 
It is not difficult to imagine that Amphion rests this hope on his quiet way of life. As we have seen, he expects that busily engaged citizens will show "concern for shameful deeds." So that kind of life threatens a "sense of proportion." Presumably, then, if Amphion thinks that he will have a "sense of proportion" and so be able to give wise advice, it is because his quiet life enables him to protect his balanced sense of right and wrong. So understood, Amphion connects the quiet life and wise citizenship.

It is perhaps surprising to see someone hold that one can mind one's own business and engage in politics. But if being unbusied (apragmosunē) is generally opposed to being nasty and meddlesome (polupragmosunē), and if there is no word for the condition of engaging in others' business without nasty meddling, then one might want to characterize the middle ground as a way of being unbusied or minding one's own business. That appears to be how Amphion sees himself. He does not entirely abandon politics, but nonetheless withdraws from the hustle and bustle of political competition in favor of research and pleasure. All told, then, he prefers the (relatively) quiet life for pleasure, intellectual inquiry, and wiser politics. ${ }^{5}$

It is not clear how Amphion would fit these aims together and balance his pursuit of pleasure, research, and the good of the city, nor is it clear how much political action or what kind of political action he would allow himself as one who minds his own business. Perhaps his position would display more obvious coherence if we had the rest of Euripides' play. Perhaps not: he is a character in a drama and not a theorist striving for consistency.

In any case, later philosophers who were eager to justify withdrawal from ordinary politics typically separated these aims. They independently prioritized just one of the three aims to argue that it would be better to live a quiet than a political life. The significance of their arguments lies not just in their ramifications for ancient ethical theory and its account of how a 
person should live. The philosophers who argue for withdrawal also challenge the dominant ideology about politics in different ways, and they all suggest an alternative conception of politics.

To offer a first approximation of how they do this, I need to tease out some of the dominant ideology's implicit commitments. The ideology explicitly holds that human excellence requires political action. If the ideology assumes, with Aristotle and many Greeks, that human excellence is the fulfillment of human nature, then it is committed to the idea that human beings are naturally political animals (see also Depew, this volume). But two other commitments offer a more relevant explanation of the dominant ideology. First, according to the dominant ideology, the good of a human's life is (at least primarily) not private and exclusive to him but shared or common; it is (at least primarily) located not in some state of himself but in activities that necessarily involve others. Second, the dominant ideology identifies these activities that necessarily involve others and (at least partly) constitute the good of a human life as the traditional activities of the active citizen. These two commitments explain why the dominant ideology holds that excellence and achieving the good so obviously require political engagement.

The three philosophical defenses of withdrawal challenge different features of the ideology and suggest different alternatives. The first, developed by Plato and Aristotle on behalf of philosophical contemplation, accepts both of the dominant ideology's implicit commitments but argues that some exceptional human beings do better by trying to transcend human nature and ordinary political activity. Like Amphion, they favor quiet study. Perhaps unlike Amphion, they think that only an exceptional few should favor quiet study, and they favor quiet study for its own sake, as the best activity a human can perform, and not for the sake of pleasure, although it is extremely pleasant. To the extent that Plato and Aristotle, and especially some heirs of their 
argument, suggest a community of like-minded people who avoid traditional political activity, they also introduce an alternative vision of a political community, and one that does not require face-to-face interaction.

The second defense of withdrawal, developed by Epicurus on behalf of pleasure, rejects the dominant ideology's first implicit commitment by arguing that the good for human beings is private — each person's good is his own pleasure and not a shared activity—and concludes that humans best realize their good outside traditional political activity. By turning their backs on the hazards of competition and embracing pleasure, including a defense of some intellectual inquiry, the Epicureans follow Amphion closely, although their concomitant embrace of a separatist community of Epicureans might well differ from his, which is uncertain.

The third defense of withdrawal, developed by Socrates and some of his followers on behalf of reforming politics, accepts that the human good lies in shared activity but rejects the second implicit commitment of the dominant ideology by radically transforming the picture of what that activity should be. On this approach, politics should not be the traditional competitive endeavor but a quiet, shared education in what is good. Perhaps this develops Amphion's proposal to offer wise counsel from a quiet life. At the least, Socrates and his followers develop Amphion's curious combination of withdrawal and engagement, and they offer various ways of developing this combination as a new kind of politics.

\section{Withdrawal to Transcend Politics}

Plato and Aristotle do not reject the dominant ideology, but their attraction to the ideal of minding one's own business leads them to plead for exceptions. They are in a difficult spot, wanting to motivate the ideal of minding one's own business without rejecting the dominant 
ideology. At first glance, it might seem that Plato succeeds in doing this by transforming what it means to mind one's own business. But in the end, the transformation is not enough. Plato is still drawn to the ideal of minding one's own business as traditionally understood, as the quiet life. He and Aristotle both argue that an elite few can live the best possible human life by withdrawing from politics, and their case for this introduces tension into their ethics and puts pressure on the dominant ideology.

Plato transforms the idea of minding one's own business in the Republic when he makes "minding one's own business" essential to justice, the paradigmatic excellence of the political life. $^{6}$ He maintains that the just person is one in whose soul each part minds its own business (Resp. 441d-e, 443c-d), and a just city is one in which each class of citizens minds its own business (Resp. 434c). This is a transformation because "minding one's own business" now has little to do with avoiding the business of the polis. Indeed, on Plato's scheme, the ruling class of the ideal city "minds its own business" (that is, it does its own job) by ruling the city! So it would appear that this transformation allows Plato to stand by the dominant ideology's rejection of withdrawal while co-opting the quiet life's ideal of "minding one's own business."

But his support for the dominant ideology is uneasy, for two reasons. First, Plato's transformed ideal of "minding one's own business" is highly restrictive. On his view, the just soul is ruled by its rational part (Resp. 441e), which must have knowledge (441e with 442c), and knowledge requires grasping the Forms, the non-sensible properties that explain the way things seem (Resp. 476a-479e with Books VI and VII). But only philosophers grasp the Forms (Resp. 476a-479e), and so only philosophers are, strictly speaking, just. On Plato's view, too, the just city is ruled by its rational part, which must have knowledge. So the just city must be ruled by 
philosophers (Resp. 473c-e). According to these standards, very few people and even fewer cities are just.

What is more, Plato holds that those who are just and who perfectly manifest the transformed ideal of "minding their own business" - that is, the philosophers-also want to mind their own business in the traditional sense of withdrawing from politics. ${ }^{7}$ According to the Republic, a philosopher who has grasped the knowable reality that underlies and explains the world of perceptual experience wants nothing so much as to continue to contemplate this reality, and so she disdains politics. That is why, in the Republic, the founders of the ideal city have to compel the philosophers to rule (see Brown 2000 and 2004). These philosophers will "mind their own business" in the transformed sense and engage in politics only if they are compelled to, and those who willingly engage in politics must, according to Plato, fail to "mind their own business" in the transformed sense. So it would seem that the transformation of "minding one's own business" fails to save Plato's attachment to the dominant ideology.

In fact, Plato expounds upon the gulf between the best, philosophical life and political activity in several dialogues. When the Republic addresses how philosophers should live in ordinary cities, it is clear that they should and will justifiably indulge their love for wisdom, far from politics (520a-b; cf. 496c-497a and 592a). In the Phaedo, Socrates insists that philosophers are completely different from anyone else, including regular citizens, for the philosophers are lovers of wisdom while everyone else is a lover of body $(68 \mathrm{~b}-\mathrm{c})$. And in his digression in the Theaetetus, he asserts that these utterly different interests involve incompatible skills: philosophers are ignorant and unable in law-courts and political proceedings (173c-d) while politicians are ignorant and unable when it comes to philosophical discussions of justice (175b- 
d). In these works, Plato urges withdrawing from politics to live the best life a human being can live, the life of contemplative philosophy.

Plato's ideal of the quiet life of contemplation is not exactly Amphion's. Amphion defends intellectual activity in part because it brings him maximal pleasure and in part because it will enable him to give political advice. Plato's contemplators are not interested in giving political advice, and while they believe that contemplation is the most pleasant activity, pleasure is not their reason for contemplating. They are attracted to contemplative activity for its own sake, on account of their love of wisdom.

The contemplative ideal might be Plato's invention. Plato himself and the later tradition attribute the contemplative ideal to some Presocratic philosophers, but it is not clear if the attribution is correct. ${ }^{8}$ It is clear, however, that Aristotle retains the contemplative ideal. This is clearest in the Nicomachean Ethics (but see also Pol. VII 2-3 and Eth. Eud. 1.4-5). In Book One, chapter five, Aristotle distinguishes four sorts of lives that people lead, and he dismisses two of them, the money-making life and the "apolaustic" life devoted to bodily pleasure. But he postpones the comparison of the political and philosophical lives. When he returns to the subject, in Book Ten, chapters seven and eight, he argues that it is better to act always for the sake of philosophical contemplation than to act always for the central activities of the political life.

Plato and Aristotle do not give all the same reasons for living a contemplative life, but they agree on two important claims. First, contemplative activity is intrinsically superior to political activity. That is why Plato's philosophers prefer it, and why Aristotle favors the philosophical over the political life. Second, the philosophical life involves transcending human 
nature to become as much like god as possible (Pl., Resp. 613a-b, Tht. 176b, Tim. 90a-d, and Arist. Eth. Nic. 1177b31-34; cf. Depew, this volume, 26-27).

These claims, in fact, introduce a tension into the ethics of Plato and Aristotle. On the one hand, both want to say that the best human life perfects human nature (see esp. Arist. Eth. Nic. 1098a7-18). But on the other hand, they acknowledge that philosophical contemplation involves acting like a god and not a human. This tension left room for disagreement. If contemplation is more than human and the best life is truly human, then perhaps the best life is political, after all. Aristotle's pupils Dicaearchus and Theophrastus disagreed about whether the philosophical life is really better than the political life (see Cic. Att. 2.16.3).

The tension lurks because Plato and Aristotle agree that the contemplative ideal is exceptional. On their view, at best a few people have the ability to transcend human nature and contemplate like the gods. In other words, Plato and Aristotle want to leave the dominant ideology largely intact: for most human beings, on their view, it is best to engage in politics (see also Depew, this volume). But their passion for the contemplative ideal calls the ideology into question, nonetheless, in three ways.

First, Plato and Aristotle threaten the dominant ideology's conception of certain fundamental values to explain why the contemplative life is best. According to the dominant ideology, excellence expresses itself in action, and action is political (see, e.g., Pl., Meno 71e and Xen. Mem. 4.2.11). But this makes it impossible to say that a contemplative philosopher who minds his own business has excellence. So Plato and Aristotle have to reject the ideology's conception of excellence and activity. Plato does it one way: when he says that the contemplative philosopher is unwilling to engage in politics, he says that she is unwilling to act (Resp. 517c), and so he rejects the connection between excellence and activity. Aristotle does it 
another: when he says that the contemplative philosopher is unwilling to engage in politics, he insists, nevertheless, that he is acting (Pol. 1325b14-32), and so he rejects the connection between activity and politics.

Sometimes, too, the contemplative ideal makes problems for the dominant ideology not by overturning its values but by making explicit tensions that were already there. So, for example, according to the dominant ideology, the best humans and poleis display selfsufficiency, but it is not entirely fixed whether self-sufficiency requires independence or is compatible with extensive alliances. Aristotle exploits this. He builds up the picture of selfsufficiency as interdependency to accommodate the political life that is the best most could hope for, and he argues that for the few, contemplation realizes the self-sufficiency of independence, which surpasses what befits human beings as political animals (Eth. Nic. 1097b6-16 and 1177a27-b1 with Brown forthcoming a).

Finally, the contemplative ideal hints at alternative politics. Consider, for example, the Academy or Lyceum as a community of people who mind their own business and share a contemplative life. Such a community offers a concrete example of a community apart from the dominant ideology's polis. Nor does the threat of an alternative community depend upon faceto-face interactions. Plato and Aristotle wrote works to exhort others to take up the philosophical life, and these writings might be viewed as tools for building dispersed philosophical communities. At least, that is the way the Roman Stoic Seneca saw the early Stoics' philosophical work when he was justifying his retirement from politics (Dial. 8.6.4). In two ways, then, those who live as contemplative philosophers, minding their own business, can see themselves as citizens of a community outside the bounds of the traditional polis. 
Plato and Aristotle do not pursue these implications of the contemplative ideal, probably because they do not want to threaten the dominant ideology. And in fact, their contemplative ideal poses no immediate threat to politics unless it becomes widely available. But Christianity, in a way, made the contemplative ideal widely available and fostered a community, not always face-to-face, that stood as an alternative to traditional politics. That is why Augustine's City of God must toil to defend the Christians. It also helps to explain why philosophers who embrace the dominant ideology rejected that contemplative ideal: they recognized the threat that that ideal posed to traditional political work. The great third-century Stoic Chrysippus, for example, rejected the life of leisure both for those who openly avow their pursuit of pleasure (Epicureans) and for those who pursue pleasure cryptically (Academics and Peripatetics) (Plut. De Stoic. rep. 1033cd). He and his Stoic followers—Seneca's On Leisure notwithstanding—agreed that "the sage will participate in politics, if nothing prevents him" (Diog. Laert. 7.121).

So, when Cicero, who wholeheartedly embraces the dominant ideology, tries to defend his beloved Plato, he gives no support to the contemplative ideal. Rather, he claims that Plato taught Dion of Syracuse to be a better citizen (Off. 1.155). Cicero, in other words, defends Plato the man against Plato the theorist. It is not hard to imagine that Plato, Aristotle, and their immediate followers would have done the same. After all, they respected the dominant ideology despite the special exceptions, and in both schools, there were in fact several philosophers who advised politicians. So perhaps, in practice, and despite the contemplative ideal, Plato and Aristotle would have defended the quiet life by citing Amphion's third reason, that it facilitates wiser political advice. 
Still, by proposing a way of life greater than politics, Plato and Aristotle call into question the dominant ideology, and their evaluative demotion of the political life had long-term consequences.

\section{Withdrawal to Reject Politics}

Epicurus also demotes the value of political activity. He believes that politics has merely instrumental value, because he thinks that everything besides pleasure has value if and only if it brings about pleasure. This private conception of the good—each person should pursue his or her own pleasure-departs radically from the dominant ideology's conception of the good. But Epicurus' understanding of pleasure is unusual, and although he generally favors the quiet life, he also lays the groundwork for a counter-cultural conception of politics.

Epicurus understands pleasure to be not sensual satisfaction but the absence of mental disturbance and physical pain. Thus, he proposes that success in life requires cultivating bulwarks against disturbance and pain and avoiding circumstances that are likely to give rise to disturbance and pain. These two strategies might be thought to pull in two different directions. After all, the better one is equipped to shrug off what would pain most people, the less one needs avoidance, and the more one avoids pains, the less practice one has absorbing troublesome circumstances without trouble. But generally speaking, Epicurus prefers the odds of avoidance, and so he counsels against the political life (Sent. Vat. 58 and RS 14; cf. Diog. Laert. 10.119 and Plut. Adv. Col. 1126e-1127c).

Of course, this is general advice, and it admits of exceptions. If no one takes charge and political instability threatens, then the calculation might change. Epicurus' pupil Colotes explains, 
Those who arranged laws and customs and established kings and rulers in cities brought much security and tranquility to life and banished turmoil. If anyone takes these things away, we shall live the life of beasts, and one man who chances upon another will practically devour him. (Plut. Adv. Col. 1124d)

This would be worse than a life engaged in politics. So, as Seneca reports, "Epicurus says that the sage will not engage in politics unless something intervenes" (Dial. 8.3.2). This no doubt explains why some Epicureans, such as Cassius, did engage during the Roman civil war in the first century BCE (see Momigliano 1941).

It is worth noting, too, that one might accept the general framework of Epicurean ethics and nevertheless infer that one should engage in politics. One need only recalculate how politics and withdrawal would promote one's private good. There is some reason to believe that Epicurus' atomist predecessor Democritus favored this alternative calculation. According to later reconstructions, Democritus held that one should act always for the sake of one's "goodspiritedness" (euthumia), and he identified "good-spiritedness" as something distinct from pleasure but reliably tracked by "enjoyment" (terpsis) (Diog. Laert. 9.45; Clem. Al. Strom. II 130; cf. fr. 189 DK). This makes his account of ethics a close cousin to Epicurus': both locate the good in a private state of the individual. But unlike Epicurus, Democritus roundly encourages politics, at least according to our surviving fragments (Plut. Adv. Col. 1126a and $1100 \mathrm{c}[=$ fr. $157 \mathrm{DK}]$ and fr. $252 \mathrm{DK})$.

The difference between Democritus' support for the dominant ideology and Epicurus' rejection of it seems to turn on a disagreement over the effects of one's reputation. The fragments of Democritus include this: 
If a man neglects the affairs of the people, he becomes ill spoken of, even if he does not steal or do anything wrong. Later, for the man who is negligent or does wrong, there is a risk of being ill spoken of and of suffering something. To err is inevitable, but it is not easy for human beings to forgive. (fr. $253 \mathrm{DK}$ )

Democritus does not encourage pursuit of the greatest honors (Plut. De tranq. anim. $465 \mathrm{c}=$ fr. 3 DK), but he does say that minding one's own business will bring trouble. That is, given the dominant ideology, one does not want the reputation of minding one's own business. Epicureans surely faced the dominant ideology's complaint that they were "free-riding" (see Plut. Adv. Col. 1127a). But Epicurus nonetheless advises his followers to "live unnoticed" (fr. 551 Usener). He seems to believe that those who engage in politics are mistaken about how best to obtain security. They think that political power and honor will give them freedom from fear ( $R S$ 7). But in fact, Epicurus maintains, it is riskier to seek security among such people than it is to try to avoid notice. The Epicureans simply calculate the risks differently than Democritus, for they, unlike him, consistently conclude that it would be better to avoid politics (see also Roskam 2007).

But Epicureanism is not entirely apolitical, and the Epicureans who mind their own business do not entirely leave politics behind. They do not withdraw to live as separate individuals, each minding his own business. Rather, they cultivate friendship with other Epicureans as the greatest security against pain and disturbance (RS 27 and 28, Sent. Vat. 34). In fact, the Epicureans lived together in Epicurus' "Garden" (see Clay 1983). They established a community of like-minded people who helped each other by providing security so that each could best pursue pleasure ( $R S 40)$. The ideals of this community departed sharply from those of 
the polis from which the Epicureans withdraw: theirs was a counter-cultural community (see Brown forthcoming b; cf. Eur. Hipp. 1013-1020).

The Epicureans do not draw attention to the fact that their Garden counts as countercultural politics. This should not be surprising; they aim to "live unnoticed." But the founder of Stoicism, Zeno of Citium, seems to have proposed a similarly counter-cultural community of friends, and he did draw attention to this in a work called Republic (Politeia). In this work, Zeno proposes an ideal political arrangement that embarrasses Plato's Republic by its impracticality. The ideal, Zeno suggests, would obtain were every adult human being a Stoic sage. Any powersharing arrangement among non-sages is doomed to faction: political peace requires likemindedness (homonoia) which requires genuine wisdom. So on Zeno's radically deinstitutionalized picture of ideal politics, a community of sages can be counted on to be friends and to educate the young to be virtuous adults. They will need no law-courts or temples. Nor will they need a military, so long as the world is filled with cities each of which is filled exclusively with sages, sharing the same, Stoic way of life.

It is hard to see how such an ideal could have any practical import, since the Stoic sage is "rarer than the Phoenix." But Zeno insisted on the relevance of his Republic right from its start (Phld. De Stoicis 12.2-8), where he also impugned the standard Greek education (Diog. Laert. VII 32). This suggests that he imagines that people might reject the standard education and seek to build a community with like-minded individuals who are committed to a Stoic education. If that is the import of Zeno's Republic, and it is not easy to be sure about this, then it resembles the lesson of Epicurus' Garden, with the challenge to traditional political theorizing made explicit (see Brown forthcoming c: chp. 6). Although Zeno and Epicurus start from very different 
assumptions about human beings and their good, Zeno's proposal highlights the political implications of Epicurus' particular way of minding his own business.

\section{Withdrawal to Transform Politics}

The third defense of withdrawing from politics accepts wholeheartedly the dominant ideology's claim that the good for a human being is activity that must be shared with other human beings, but it rejects the thought that this activity can be found in ordinary politics. Its sponsor is Socrates, at least as he appears in Plato's Socratic dialogues. ${ }^{9}$

Socrates uses paradox to characterize his attitude toward the political life: "It might perhaps seem strange that I go around giving advice and minding others' business privately but do not dare to go into your assembly and advise the city publicly" (Pl., Ap. 31c4-7). This is paradoxical because Socrates considers himself both a busybody (polupragmōn) and yet outside traditional politics. But he fully explains the paradox.

On the one hand, Socrates explains his rejection of traditional politics. He acknowledges that he gave Athens conventional political service on each of the three or four occasions when his city called upon him: he fought in battles at Potidaea, Amphipolis, and Delium (Pl., Ap. 28de; cf. La. 181b); he was at least once—but not more than twice ([Arist.] Ath. Pol. 62.3)—a member of the Council of Five Hundred (Pl., Ap. 32b1); and when the Thirty summoned Socrates to carry out an order, he answered the call, though he refused to carry out the order (P1., Ap. 32c4-d7). But the divine voice has told him to keep away from engaging in politics (P1., Ap. 31d2-5), and Socrates believes that it is entirely right to do so (Pl., Ap. 31d5-6). He explains,

For know well, men of Athens, that if I had long ago tried to engage in political affairs, I would have long ago perished and would have benefited neither you nor myself. Do not 
be angry with me when I speak the truth, for no one at all will survive if he genuinely opposes either you or any other assembly and prevents many injustices and illegalities from occurring in the city. Rather, anyone who really fights on behalf of the just, if he is going to survive for even a short time, must live privately, and not publicly. (Pl., $A p$. 31d6-32a3)

In order to benefit himself and the Athenians, Socrates believes that he had to withdraw from the traditional political life. So Socrates lived a philosophical life that "minds its own business" (cf. Pl., Grg. 526c).

Yet, on the other hand, Socrates did not live a life of quiet contemplation (cf. P1., Ap. 36b), and he did not withdraw from the business of helping the general public, for he believed that his examinations provide the greatest benefit to Athens that anyone could provide (P1., Ap. 36c). This explains why he also characterizes himself as a "busybody" (Pl., Ap. 31c, quoted above), and it explains why he insists, in Plato's Gorgias, that he is the only Athenian of his time even to try to engage in true politics, which is to say, he is the only one who tries to improve others' lives instead of trying merely to make them feel better (521d).

Socrates, then, is a special case, and his argument for withdrawing from ordinary politics depends upon rethinking what politics should be. He rejects thoroughly the values of contemporary Athenians, their love of honor and wealth (Pl., Ap. 36b et passim), and he argues instead that no one should engage in the affairs of the city before straightening out the affairs of his own soul (cf. P1., Symp. 216a). Socrates in a way inherits a traditional aristocratic rejection of democratic politics. But instead of offering reactionary proposals, he radically rethinks what politics should be. He opposes not just the values of the Athenian democrats but also those of their oligarchic rivals. That is why Callicles is right to draw on Zethus' critique of Amphion 
when he wants to cast Socrates as someone who neglects traditional political values and activities (Pl., Grg. 485e-486d).

How special Plato's Socrates is can be seen by looking at Isocrates, who offers a rival conception of how to transform politics through a life that minds its own business. Isocrates is Plato's chief rival for students who wish to study what both call "philosophy." But whereas Plato's students learn to study and contemplate the nature of the world, and to reshape their lives in accordance with what they discover, Isocrates promises a more narrow revision of traditional rhetorical training, revamped to suit more aristocratic aims than those served by other fourthcentury orators. Accordingly, he stays closer to the traditional aristocratic ideal of "minding one's own business." He attacks earlier and rival rhetoricians for teaching "busybodiness" (polupragmosunē) (C. soph. 20 and Antid. 48, 230, 237). He cultivates instead being unbusied (apragmosunē) (Antid. 4, 151, 227), and he defends himself against the charge of having taught busybodies (polupragmosunē) (Antid. 98). Isocrates uses his writings to try to change Greek politics, but his aims are far less radical than Socrates'. He yearns for a return to past glory that attracted Greek allies to Athens' leadership and kept the barbarians at bay (see, e.g., Aerop. 79$81)$.

So Socrates' life was unusual, both because it simultaneously minded its own business and meddled and because it thoroughly critiqued traditional political values. But it is not easy to see what the concrete political implications of Socratic politics are. How would a polis be arranged if all the citizens successfully examined themselves and each other? Socrates, like some other prominent political theorists-Marx leaps to mind — is clearer about what is wrong with the status quo than he is about how things would be if they were set right. 
Perhaps because he was so unusual and perhaps because his vision of an alternative future was indeterminate, Socrates attracted a wide range of followers. In a way, Plato's and Aristotle's thoughts about how a city ought to be governed respond to Socrates' call for reform, as they insist that rulers should be the most virtuous people, but Aristotle, especially, shows how the Socratic conception of virtue can be tamed to accommodate traditional Athenian values. Other so-called "Socratic" followers stay closer to the radical challenge that Socrates presents to business as usual, although they differ widely in their interpretation of how to reform politics and realize the aim of benefiting others.

The Cyrenaics and Cynics both go further than Socrates in removing themselves from traditional politics. Like Socrates, they avoided the assembly and the courts and thereby rejected the traditional political life. But Socrates, despite his philanthropic (Pl., Eu. 3d) desire to examine and benefit "anyone, whether fellow citizen or foreigner, whom I think is wise" (Pl., Ap. 32b, cf. 30a), stayed in Athens. He need have not thought that he was obligated to benefit the Athenians especially. He might simply have thought that Athens, with its free speech, best suited his controversial way of life (Pl., Grg. 461e; cf. Ap. 37c-e and Meno 80b). Nonetheless, he did not renounce his ties to Athens. The Cyrenaics and Cynics, by contrast, noisily rebuked local attachments. Aristippus the Elder, who is in some sense the founder of the Cyrenaic sect, says, "I do not shut myself up in a political community but am a stranger everywhere" (Xen. Mem. 2.1.13; cf. Plut. an virt. doc. possit 2, 439e). The later Cyrenaic Theodorus names the cosmos his father-city (patris) (Diog. Laert. 2.99). And, most noisily of all, Diogenes the Cynic declares himself a "citizen of the world" (Diog. Laert. 6.63) and embraces his existence "citiless, homeless, deprived of a fatherland" (Diog. Laert. 6.38). These cosmopolitan Socratics spread 
sharply contrasting visions of the good human life, but both Cyrenaics and Cynics were clearly inspired by Socrates' conception of politics outside the traditional bounds. ${ }^{10}$

The Stoics, whose founder apparently studied with the Cynic Crates and in the Academy (Diog. Laert. 7.2), offer a more nuanced response to Socrates' example. On the one hand, they partly rehabilitate traditional political engagement and the dominant ideology. At least by the time of Chrysippus, Stoics believe that one should engage in politics if the circumstances permit (Diog. Laert. 7.121), and Chrysippus even allows that a Stoic might speak in public as though wealth and health were good even though Stoicism holds that only virtue is, strictly speaking, good (Plut. De Stoic. rep. 1034b; cf. 1048a). There seems to have been no fixed political program in the Stoa, as different circumstances would call for different regimes and laws to achieve the aims of politics, which are to restrain vice and promote virtue. But the Stoics attempt to join Socrates' uncompromising views about value with traditional political action.

On the other hand, the Stoics also insist, with Socrates and against the dominant ideology, that a good human life does not require traditional political engagement. It requires, instead, agreeing with nature, and this demands sensitivity to the particular circumstances in which one finds oneself. So one person might do best by engaging in politics, and another as a private farmer, and a third as a philosophical teacher. Here the Stoics resemble the other philosophers in seeking to divorce the notions of excellent activity and traditional politics, but like Socrates - and unlike the advocates of contemplative activity or pleasant withdrawal — the Stoics do this by transforming the notion of politics and by yoking all excellent activity to the inherently political project of seeking a common good with other human beings. For them, even the private life of philosophical teaching is the life of a political animal, and its excellent activity aims at a common good with other humans just as surely as the traditional political life does (see 
Brown forthcoming c: chapter 7). So the Stoics remain true to the Socratic revolution in rethinking the aims and means of politics even though they encourage traditional forms of political action to realize this revolution.

With time, the contrast between the Cynic and the Stoic response to Socrates became more pronounced. Especially once Stoicism settled in Rome, Stoic ideas drifted further from their radical roots, and they were frequently joined to conventional Roman ideals. But interestingly, philosophers in the Roman world who often espouse Stoic-Roman ideals that are opposed to the radical proposals of Socrates and the early Socratics continue to make a special exception for Socrates and his immediate followers. So, for example, Cicero declares,

No one should be led into this error, that if Socrates or Aristippus did or said something contrary to custom or political practice, this same thing should be permitted to him. For those men acquired such freedom by their great and divine goods. But the whole theory or approach of the Cynics must be rejected. (Off. I 148)

Seneca goes one step further, and finds room to praise Diogenes the Cynic. He says, "In benefits, I am necessarily defeated by Socrates, necessarily defeated by Diogenes, who marched naked through the middle of the Macedonians' treasures, treading upon the wealth of a king" (Ben. V 4.3). These accommodations suggest that the Socratic challenges to the dominant ideology are allowable only as exceptional provocations to virtue. Broader allegiance to the Socratic program, such as one finds in the vogue for Cynicism in first- and second-century (CE) Rome, would have to be tamer (see Billerbeck 1996).

\section{Contesting the Political}


Philosophers in antiquity sought to justify the quiet life against the dominant ideology's insistence that excellence requires engaging in the affairs of the polis in the assembly and the courts. It is not hard to find in these arguments an appearance of rationalization or selfjustification. But I have tried to show why it would be a mistake to dismiss these arguments or set them apart from "Greek and Roman political thought." By these arguments, the philosophers raise, sometimes merely implicitly and sometimes explicitly, deep and important questions about politics. Some of them merely challenge the values and virtues of the political agents around them. More searchingly, some of them go one step further, and offer a model of political activity that is not confined by the geography and institutions of the polis. When we are asking about what politics is, who does or should engage in politics, and how they should do so, these challenges matter.

\section{FURTHER READING}

The best study of Greek withdrawal from politics is Carter 1986, which covers the last third of the fifth century as the background to Plato's defense of the contemplative life. There is no adequate survey in English of the long-standing philosophical dispute between the philosophical and political lives. Perhaps the best work remains Jaeger 1928/1948. In French, there is Joly 1956, which should be read warily. Also relevant are André 1966, Demont 1990, and Grilli 1953. For more specialized inquiries, see the notes and citations. 
Ryan Balot proposed this chapter, offered many helpful suggestions for developing the chapter, and improved it with his critique of a penultimate draft. I am very grateful to him for all of this and for much else.

There are other senses of "minding one's own business" that I leave aside in this chapter. Consider how Pericles attacks those who "mind their own business" in his final speech in Thucydides' history (2.63.2-3). Here those who "mind their own business" are attempting to persuade their fellow Athenians to surrender their empire (see also 2.64.1 for the attempt to persuade and the 2.64.4 for the opposition to empire). So they are not entirely minding their own business. Perhaps, then, "minding one's own business" is a relative term, always understood by contrast to some state of "busybody-ness" or "meddlesomeness" (polupragmosunē). (Compare the discussions of Amphion and Socrates below.) Often, the terms do work this way, and with wide variability: what is considered meddlesome varies because different people in different circumstances are expected to take different degrees of interest in the affairs of another (see Adkins 1976). For the most part, I set this aside, to concentrate on "minding one's own business" where it indicates withdrawal from politics. On the other hand, and perhaps more likely, Pericles might identify the anti-imperialists as "minding their own business" not because they are less meddlesome but because they want Athens to "mind its own business" and surrender its empire. (Thucydides has the Corcyraean envoys say that Corcyra was formerly committed to minding its own business

(apragmosunē) (1.32.5). Compare Arist., Pol. 7.2-3.) It is doubtful that the anti-imperialists themselves would embrace this label, since it smears them with political inexperience and inattention, but "minding one's own business" and "meddlesomeness" were often slogans in debates over Athenian foreign policy (see Ehrenberg 1953 and Kleve 1964). I set this usage 
aside, as well. For the identity of the anti-imperialists Pericles targets, see Nestle 1926, Wade-Gery 1932, and Dienelt 1953. And with Pericles' attack, compare how Alcibiades characterizes Nicias' opposition to the Sicilian expedition as "minding one's own business" (apragmosunē) (Thuc. 6.18.6).

2 For the dominant ideology's transformation of Homeric values, see Adkins 1960. Wallace (in this volume) excellently situates this ideology. Rahe 1984 reflects expansively on it. 3 Carter 1986 discusses the historical quietists in fifth-century Athens by inferring their existence from largely literary evidence. Although he does not name many names, he identifies three distinct groups: the nobles who withdrew from the democratic regime they could not support (e.g., some of the youths in Socrates' circle); the peasant farmers of Attica who had neither the time nor the money to go to the assembly or the courts in Athens (e.g., various characters in Euripides' and Aristophanes' plays); and rich quietists, some of them who could not engage because they were metics, who feared prosecution and entanglement (e.g., some of Lysias’ defendants).

4 The source for this fragment does not name the play. Nothing much turns on whether it comes from Antiope. For my purposes, it is enough that Zethus' charges establish that Amphion was engaged in intellectual inquiries of some sort. That sets up the need for Amphion to defend such inquiries. If this fragment does not record his defense, it at least expresses a related idea, and thus introduces one of the three motivations for withdrawal that I want to explore.

5 North says that "minding one's own business," "the watchword of the aristocrats" in the fifth century, was later "absorbed into the Attic ideal of citizenship" (North 1966: 137). This seems to me to go too far. There remains in the fourth century BCE (and beyond) an element 
of detachment in "minding one's own business," and there remained people who insisted on "minding their own business" by staying out of politics altogether. Notice that in the Oration on the Scrutiny of Evandrus that North immediately cites, Lysias warns that Evandrus will contrast his life minding his own business with most Athenians' (26.4).

6 In the Charmides (161b-163d), Socrates is less optimistic about "minding one's own business" as a characterization of virtue (in this case, moderation or temperance).

7 In the Statesman (305e-309b), the Eleatic Stranger explains that people who are keen to mind their own business are those with the quiet nature that is associated with moderation or temperance, as opposed to those with the lively nature associated with courage and the warring life. But one should not suppose that the philosophers of the Republic have quiet natures. Rather, they manifest a blend of both natures, just the sort of blend that the Stranger wants the statesman to bring about in the citizens. But notice the similarity between the Stranger's complaint about the quiet natures (at 307e) and the wife's complaint about the father who minds his own business in Republic VIII (549c-d, quoted above).

8 Jaeger 1928/1948: 429, for example, doubts it. The strongest contender would seem to be Anaxagoras. See DK 59A29-30. If Euripides studied with him (Diog. Laert. 2.10), Anaxagoras' leanings toward a contemplative life might also help to explain Euripides' Amphion (or whoever speaks fr. $910 T G F$ ).

9 Xenophon's Socrates is at least sometimes a very different character, who endorses the dominant ideology and encourages political engagement. See especially Mem. 3.7.

10 For an excellent survey of cosmopolitan ideas from Greek antiquity, see Konstan (in this volume). 